\title{
KAMPANYE PRODUK MINUMAN KESEHATAN MELALUI GAMES INTERAKTIF
}

(Studi Kasus Go Sweat Go Ion Game Sebagai Media Kampanye Pemasaran Produk Pocari Sweat)

\author{
Rheza Ramadhyan Wicaksana, Atwar Bajari \\ Fakultas Ilmu Komunikasi, Universitas Padjadjaran
}

\begin{abstract}
ABSTRAK
Aplikasi Game adalah model permainan interaktif antara manusia dengan mesin sebagai penyedia menu permainan. Memainkan game membuat orang merasa terhibur dan sekaligus memacu ekspektasi kemenangan. Bagi orang marketing, substansi atau isi permainan game dapat digunakan sebagai media persuasi bagi strategi pemasaran produk. Karakter interaktif game membangun hubungan intens antara iklan dengan calon konsumen. Tujuan penelitian ini mengupas kemampuan game interaktif sebagai media kampanye bagi tujuan pemasaran produk minuman isotonik yang berasal dari Jepang. Metode penelitian yang digunakan adalah studi kasus. Penelitian ini dilakukan terhadap game interaktif yang digunakan di Indonesia (versi Indonesia), di mana pemanfaatan game sebagai media kampanye ini tergolong baru. Sampai saat ini belum ada strategi pemasaran demikian yang dilakukan untuk memasarkan produk di Indonesia. Hasil penelitian menunjukkan bahwa, game menjadi tools of marketing yang baik dan mendorong pengguna untuk bergerak seiring instruksi pada game. Salah satu parameternya adalah pada saat penelitian dilakukan pada 2014, game sudah didownload oleh sekitar 15.365 pengguna dengan komentar dan opini di media sosial (facebook dan twitter) untuk game iklan ini cukup tinggi.
\end{abstract}

Kata-kata Kunci: Game, kampanye, komunikasi pemasaran, advergame

\section{HEALTHY DRINK PRODUCT CAMPAIGN THROUGH INTERACTIVE GAMES}

(Case Study “Go Sweat Go Ion Game” As Pocari Sweat Marketing Product Campaign Media)

\begin{abstract}
Game Application is an interactive game model between man and game provider machine. Playing games makes people felt entertained and victories expectation at the same time. In marketing, substance or content of the game can be used as persuasion media in product marketing strategy. Interactive game characteristic builds an intense relationships between adversisement and prospective customers. The purpose of this research is to explore interactive gaming capabilities as a media campaign for Japan originated isotonic drink marketing. Method used in this research is case study approach. The research is done to interactive game in Indonesia (Indonesian version), where games as a medium of promotion is relatively new. Until now, there is no marketing strategies that using games to market the product in Indonesia. The results show that the game becomes a good tools of marketing which encourages the user to follow the instructions in the game. One of the parametre is when this research conducted in 2014, the Go Sweat Go Ion game has been downloaded by about 15.365 users with high comments and responses on social media (facebook and twitter).
\end{abstract}

Keywords: Game, campaign, marketing communications, advergame 


\section{PENDAHULUAN}

Go Sweat Go Ion merupakan sebuah aplikasi game produk Pocari Sweat yang menyediakan product knowledge dan game yang dapat dimainkan melalui smartphone berbasis iOS \& Android. Permainan itu sendiri bisa dinduh secara gratis melalui Google Play atau App Store. Aplikasi digital ini diluncurkan pada tanggal 31 Oktober 2013, yaitu bersamaan dengan dimulainya kampanye komunikasi pemasaran Pocari Sweat dengan nama yang sama, yaitu kampanye Go Sweat Go Ion.

Melalui kampanye ini, Pocari Sweat mencoba mengajak masyarakat untuk lebih aktif bergerak. Motivasi utamanya adalah mengajak orang Indonesia untuk bergerak atau membakar kalorinya. Seperti diketahui bahwa jika dibandingkan dengan penduduk di dunia, hanya $37 \%$ penduduk Indonesia yang aktif melakukan olah raga dalam aktivitas sehari-hari yang mengandung unsur gerak dominan.

Mempertimbangkan kondisi yang dirasakan tersebut, produsen Pocari Sweat meluncurkan sebuah game yang berusaha mengajak untuk bergerak dan bergembira. Kampanye lewat game itu dibuat untuk menghilangkan rasa jenuh para pemain (to have fun), dan juga mengajak mereka untuk melakukan berbagai aktivitas "gerak". Biasanya sebuah game konvensional hanya membuat pemain berdiam dalam satu posisi tertentu dengan hanya menggerakkan jari-jarinya dan sedikit geseran badan. Game Go Sweat Go Ion lebih dinamis. Berbagai aktivitas seperti jumping (melompat), running (berlari), smashing (menangkis) didesain sedemikian rupa sebagai konten game tanpa mengabaikan aspek-aspek esensial dari sebuah game, seperti animasi, poin, leaderboard, maupun reward yang diberikan kepada pemain.

Terobosan baru tersebut menjadi bagian dalam kampanye Pocari Sweat lewat Game Go Sweat Go Ion untuk memasarkan produknya. Pemasaran Pocari Sweat dengan pendekatan Game dinamis ini dikelola oleh sebuah perusahaan agency digital bernama XM Gravity. Berbagai latar belakang dan objective menjadi sebuah alasan tersendiri bagi XM Gravity dalam memilih game sebagai media penyampaian pesan pemasaran untuk memasarkan Pocari Sweat. Termasuk salah satunya adalah pesatnya perkembangan teknologi sebagai penunjang media game saat ini. Disamping itu, tingginya jumlah pengguna smartphone dan pengguna layanan data berbasis online di Indonesia menjadi salah satu alasan terkuat dalam pemilihan media game.

Berdasarkan data yang diperoleh, terdapat \pm 230 juta pelanggan telepon seluler di Indonesia dimana \pm 30 juta pengguna diantaranya adalah pengguna telepon pintar (smartphone) dan \pm 60 juta pengguna diantaranya adalah pengguna layanan data internet melalui telepon selulernya (AdReach, 2013). Demikian juga laporan Mobo Market di kuartal ke-4 tahun 2014, menunjukkan bahwa ternyata pengguna smartphone di Indonesia lebih suka mengunduh game.

Angka ini hampir setengah dari pengguna MoboMarket. Mobile Data Report Based on MoboMarket Users Data Research. Sejak aplikasi itu diperkenalkan pada Februari 2014, telah memiliki sekitar 2,8 juta pengguna aktif bulanan di Indonesia. Game merupakan aplikasi yang paling banyak diunduh oleh para pengguna yakni sebanyak 43 persen. Setelah game, media sosial sebanyak 12 persen, dan aplikasi foto sebanyak 11 persen. (Alia, 2015)

Alasan lainnya adalah game ini ingin menyasar anak-anak muda yang malas untuk bergerak dan berkeringat tetapi tetap ingin hidup sehat dengan lebih aktif bergerak melalui cara-cara yang mereka senangi. Salah satunya adalah melalui game. Mereka adalah anak muda dengan kriteria senang bermain video games, tidur, menonton tv, dan berkumpul (hang out) dengan teman-temannya.

Perkembangan game yang kian melesat saat ini membuat permainan atau game menjadi lebih menarik karena terdapat elemen-elemen seperti visual, audio, dan interaksi, sehingga game memiliki banyak peminat mulai dari anakanak hingga orang dewasa (Wibawa, 2010). Tak hanya itu, game juga dikembangkan ke dalam bentuk mobile atau biasa disebut mobile game. Mobile game adalah game yang dapat dimainkan pada mobile phone, smartphone, PDA, ataupun komputer tablet. Game pada smartphone saat ini merupakan salah satu jalan keluar untuk menikmati hiburan dimana saja dan kapan saja.

Besarnya minat masyarakat pada game, mendorong pesatnya pertumbuhan produksi game baik secara kualitatif maupun kuantitatif. Secara kualitas, jika dahulu game mobile hanya game sederhana seperti Snake dan Tetris, sekarang ini dengan berkembangnya teknologi 
pada gadget/smartphone, menjadikan mobile game menjadi kian maju. Hal ini didukung oleh munculnya processor dualcore, dan quad-core untuk smartphone, serta teknologi video card pada smartphone yang semakin berkembang,

Genre game juga menjadi bervariasi dengan adanya layar yang lebih besar, dan didukung dengan teknologi touchscreen. Hal ini tentunya membuat game jenis mobile ini menjadi terus diminati dari berbagai kalangan. Selain hardware, sistem operasi pada gadget/ smartphone juga berpengaruh pada pesatnya perkembangan dunia game gadget/smartphone. Beberapa tahun belakangan, Blackberry OS, iOS dari Apple, dan Android dari Google Inc. menjadi sistem operasi mobile yang sangat populer dan banyak digunakan.

Perkembangan terbaru, kebutuhan industri game dengan industri pemasaran produk, adalah potensi interaktif dan daya tarik game digabungkan dengan kebutuhan para pemasar produk barang (seperti makanan dan minuman) untuk menjangkau konsumen secara lebih baik. Akhirnya memunculkan konsep advergame, yakni kontens barang atau produk yang dijual, disajikan dalam permainan game. Misalnya, minuman kesehatan disajikan secara interaktif dalam game yang mendorong untuk berolahraga. Juga kebutuhan pada kemampuan untuk meningkatkan kemampuan berbahasa asing digabung dengan games yang menantang orang menebak atau mengisi teka-teki berbahasa asing.

Advergame saat ini merupakan salah satu media komunikasi pemasaran yang sedang populer karena dianggap jitu, baik untuk kegiatan branding maupun menjaring para calon konsumen. Pada tahun 2007, nilai bisnis untuk advergame saja di Amerika telah mencapai sekitar 260 juta dolar AS. Studi dan penelitian yang dilakukan pada saat itu menunjukan bahwa kurang dari satu persen pengguna internet yang benar benar memperhatikan banner-ads, iklan pop-up, serta fitur pop-up lainnya yang banyak dianggap mengganggu oleh pengguna internet lainnya. Internet belum benar-benar terbukti sebagai suatu "branding tools" yang efektif sehingga semakin banyak perusahaan saat ini yang beralih ke "advergame".

Video game sekarang telah menjadi sarana beriklan atau membangun brand awareness yang efektif, baik melalui internet maupun di dalam event- event promosi. Advergame terasa semakin dibutuhkan untuk menjaring calon konsumen melalui promosi online yang dilakukan.

Seperti dibatasi dalam pengertian dunia bisnis, advergame menjadi tools baru yang khas untuk menjangkau khalayak sasaran. Misalnya bussines dictionary menjelaskan bahwa;

A video game which in some way contains an advertisement for a product, service, or company. Some advergames are created by a company with the sole purpose of promoting the company it self or one of its products, and the game may be distributed freely as a marketing tool. Other times, an advergame can be a regular popular video game, which may be sponsored by a company, and include advertisements within the game for the sponsoring company; for example you might see a character drink a particular brand of soft drink, or a race car might drive past a billboard advertising a certain snack food. Advergames have become more popular with the rise of the internet. (WebFinance, 2015).

Advergame adalah media komunikasi pemasaran (selain media mainstream) yang sedang populer dan banyak digunakan di seluruh penjuru dunia. Salah satu keunikan yang ada adalah seperti yang dilakukan melalui game Go Sweat Go Ion yang dikelola oleh XM Gravity. Penulis tertarik untuk meneliti advergame Go Sweat Go Ion yang dikelola oleh XM Gravity sebagai salah satu media komunikasi pemasaran dari Pocari Sweat.

Pocari Sweat sebagai pelopor penggunaan game online sebagai media komunikasi pemasaran dalam industri minuman ion tubuh di Indonesia menjadi sebuah kajian menarik dalam dunia komunikasi khususnya dalam kajian komunikasi pemasaran. Hal ini tentunya tidak terlepas dari peran besar XM Gravity selaku pengelola game tersebut, mulai dari merancang, eksekusi, hingga evaluasi penggunaan game tersebut sebagai media komunikasi pemasaran Pocari Sweat.

Pertanyaan dalam penelitian yang diajukan dalam penelitian ini adalah: (1) Mengapa XM Gravity menggunakan game Go Sweat Go Ion sebagai media kampanye pemasaran produk Pocari Sweat?, (2) Bagaimana komunikator menggunakan game Go Sweat Go Ion sebagai 
media kampanye pemasaran produk Pocari Sweat?, (3) Bagaimana konsep pesan dalam game Go Sweat Go Ion sebagai media kampanye pemasaran produk Pocari Sweat?, (4) Bagaimana penggunaan saluran game Go Sweat Go Ion sebagai media kampanye pemasaran produk Pocari Sweat?, (5) Siapakah khalayak sasaran dalam kampanye pemasaran produk Pocari Sweat yang menggunakan game Go Sweat Go Ion ini?, dan (6) Bagaimana efek yang diharapkan dalam game Go Sweat Go Ion sebagai media kampanye pemasaran produk Pocari Sweat?

Berdasarkan pertanyaan penelitian yang telah disebutkan sebelumnya, maka tujuan dari penelitian ini adalah untuk (1) Mengetahui latar belakang XM Gravity menggunakan game Go Sweat Go Ion sebagai media kampanye pemasaran produk Pocari Sweat, (2) Mengetahui bagaimana komunikator dalam menggunakan game Go Sweat Go Ion sebagai media kampanye pemasaran produk Pocari Sweat, (3) Mengetahui bagaimana pesan dalam game Go Sweat Go Ion sebagai media kampanye pemasaran produk Pocari Sweat, (4) Mengetahui bagaimana penggunaan saluran game Go Sweat Go Ion sebagai media kampanye pemasaran produk Pocari Sweat, (5) Mengetahui bagaimana sasaran kampanye pemasaran produk Pocari Sweat yang menggunakan game Go Sweat Go Ion ini, (6) Mengetahui bagaimana efek yang diharapkan dalam game Go Sweat Go Ion sebagai media kampanye pemasaran produk Pocari Sweat.

Penulis mengharapkan agar penelitian ini dapat menjadi sumbangan pemikiran terhadap kajian ilmu komunikasi. Selain ingin memberikan informasi mengenai inovasi baru dalam melakukan Program pemasaran, penelitian ini diharapkan dapat menjadi masukan bagi siapa saja yang sudah atau akan menggunakan Game sebagai Media untuk program komunikasi pemasaran yang inovatif. Penelitian ini juga bisa menjadi referensi bagi praktisi Pemasaran dalam merancang suatu game untuk program komunikasi pemasaran produk ataupun jasa.

\section{METODE PENELITIAN}

Penelitian ini mengungkap tentang penggunaan game sebagai media kampanye. Metode yang digunakan adalah metode kualitatif, dengan model pendekatan studi kasus (case study), sebab tujuan studi kasus adalah meningkatkan pengetahuan mengenai peristiwaperistiwa komunikasi kontemporer yang nyata dalam konteksnya (Yin, 2010). Riset studi kasus memungkinkan peneliti mengumpulkan informasi yang detail yang mencakup dimensi sebuah kasus tertentu atau beberapa kasus kecil dalam rentang yang luas.

Studi kasus dapat menyoroti beberapa faktor yang mengatur komunikasi dalam situasi tertentu dan melukiskan keunikannya (dalam Daymon dan Holloway, 2008: 162). Pendekatan ini juga dipilih terkait dengan pertanyaan penelitian. Seperti yang dikemukakan Yin (1988) bahwa studi kasus dapat digunakan untuk menjawab pertanyaan penelitian berupa "bagaimana" (how) dan "mengapa" (why). Dijelaskan lebih lanjut, bahwa kedua pertanyaan yang digunakan dalam penelitian tersebut mengindikasikan perlunya eksplorasi terhadap permasalahan yang ingin dijawab melalui penelitian.

Dalam penelitian ini, peneliti menggunakan metode desain studi kasus tunggal, karena desain studi kasus tunggal memberi kemungkinan untuk melakukan eksplorasi mendalam (tapi spesifik) tentang kejadian tertentu (atau beberapa peristiwa) dari sebuah fenomena (dalam Daymon dan Holloway, 2008: 166).

\section{HASIL DAN PEMBAHASAN}

Latar Belakang XM Gravity Menggunakan Game Go Sweat Go Ion Sebagai Media Kampanye Pemasaran Produk Pocari Sweat. Pada dasarnya kampanye go sweat go ion itu sendiri merupakan sebuah usaha komunikasi yang di rancang untuk tujuan menyadarkan anak muda untuk aktif bergerak dan berkeringat. Dalam menetapkan tujuan komunikasi tentu saja ada beberapa hal yang harus di lihat, hal ini seperti yang di jelaskan oleh Devito (2011: 30), ada empat tujuan komunikasi yang perlu dikemukakan yakni:

Pertama, untuk menemukan. Salah satu tujuan utama komunikasi adalah penemuan diri (personal discovery). Bila anda berkomunikasi dengan orang lain, anda belajar mengenai diri sendiri selain juga tentang orang lain. Dengan berbicara tentang diri kita sendiri dengan orang lain, kita memperoleh umpan balik yang berharga mengenai perasaan, pemikiran, dan perilaku kita. Cara lain untuk melakukan 
penemuan diri melalui proses perbandingan sosial, melalui pembandingan kemampuan, prestasi, sikap, pendapat, nilai, dan kegagalan kita dengan orang lain. Kedua, untuk berhubungan. Salah satu motivasi kita yang paling kuat adalah berhubungan dengan orang lain, membina dan memelihara dengan orang lain. Kita ingin merasa dicintai dan disukai dan kita juga ingin mencintai dan menyukai orang lain. Kita menghabiskan banyak waktu dan energi komunikasi kita dalam membina dan memelihara hubungan sosial. Ketiga, untuk meyakinkan. Kita menghabiskan banyak waktu untuk melakukan persuasi antarpribadi, baik sebagai sumber maupun sebagai penerima. Dalam perjumpaan antarpribadi sehari-hari, kita berusaha untuk merubah sikap dan perilaku orang lain, berusaha untuk mengajak mereka melakukan sesuatu. Dan keempat, untuk bermain. Kita menggunakan banyak perilaku komunikasi kita untuk bermain dan menghibur diri. Demikian pula banyak dari perilaku komunikasi kita dirancang untuk memberikan hiburan pada orang lain. Adakalanya hiburan ini merupakan tujuan akhir, tetapi adakalanya ini merupakan untuk mengikat perhatian orang lain sehingga kita dapat mencapai tujuan-tujuan lain (Devito, 1997: 30).

Seperti yang sudah dijelaskan oleh Devito, salah satu tujuan dari kampanye ini adalah untuk bermain. Dalam hal ini proses komunikasi yang terdapat di dalam dari kampanye go sweat go ion ini mengadung unsur fun karena menggunakan media game yang seperti kita tahu, game umumnya di gunakan untuk sebuah hiburan. Namun tujuan utama dari game ini sendiri bukan berakhir untuk bermain saja, namun ada tujuan lain yang tidak kalah penting yaitu untuk merubah pandangan anak muda bahwa bergerak dan berkeringat itu baik untuk kesehatan mereka, tujan perubahan pandangan tersebut sebenarnya di harapkan agar ketika anak muda melakukan kegiatan bergerak dan berkeringat mereka ingat untuk mengkonsumsi produk pocari sweat yang membantu untuk mengganti cairan tubuh yang hilang saat melakukan kegiatan yang mengeluarkan keringat.

Menurut Charles U. Larson (1992) Kampanye dibagi ke dalam tiga kategori (Venus, 2005: 11), yakni: Product-oriented campaigns, candidate-oriented campaigns, dan ideologically or cause oriented campaigns.

Product-oriented campaigns ataukampanye yang berorientasi pada produk umumnya terjadi di lingkungan bisnis. Istilah lain yang sering dipertukarkan dengan kampanye jenis ini adalah commercial campaigns atau corporate campaign. Motivasi yang mendasarinya adalah memperoleh keuntungan finansial. Candidateoriented campaigns atau kampanye yang berorientasi pada kandidat umumnya yang dimotivasi oleh hasrat untuk meraih kekuasaan politik. Karena itu jenis kampanye ini dapat juga disebut sebagai political campaigns (kampanye politik). Tujuannya antara lain adalah untuk memenangkan dukungan masyarakat terhadap kandidat-kandidat yang diajukan partai politik agar dapat menduduki jabatan-jabatan politik yang diperebutkan lewat proses pemilihan umum. Terakhir, ideologically or cause oriented campaigns adalah jenis kampanye yang berorientasi pada tujuan-tujuan yang bersifat khusus dan sering kali berdimensi perubahan sosial. Karena itu kampanye jenis ini dalam istilah Kotler disebut sebagai social change campaigns, yakni kampanye yang ditujukan untuk menangani masalah-masalah sosial melalui perubahan sikap dan perilaku publik yang terkait.

Komunikator dalam Menggunakan Game Go Sweat Go Ion sebagai Media Kampanye Pemasaran Produk Pocari Sweat. Dalam suatu kampanye tentunya harus ada komunikator yang menyampaikan pesan atau konten dalam suatu kampanye. Dan untuk mengetahui efektivitas suatu media kampanye, maka peran dan siapa komunikatornya pun akan menjadi pengaruh penting. Apakah komunikator tersebut merupakan orang yang berkredibilitas dalam media kampanye yang digunakan. Apakah komunikator tersebut mampu mewakili pesan yang ingin disampaikan. Apakah komunikator tersbut dapat menggunakan media yang dipilih sehingga media kampanye tersebut menjadi media yang efektif.

Zalmant.dkk (dalam Venus, 2005) membagi tim kerja kampanye dalam dua kelompok, yakni leaders (Pemimpin atau tokoh) dan supporters (pendukung). Dalam kelompok leaders terdapat kordinator pelaksana, penyandang dana, petugas administrasi kampanye, dan pelaksana teknis. Sedangkan dalam kelompok supporters terdapat petugas lapangan dan simpatisan yang meramaikan kampanye.

Dalam kasus ini, leaders atau tokoh atau pemimpin kampanye ini dapat diibaratkan 
sebagai Bagian Tim XM Gravity yang memang bertugas untuk melaksanakan dan bertanggung jawab atas segala kegiatan Pocari Sweat dalam bentuk digital activity. Sedangkan dalam komunikator dengan kategori supporters adalah Brand Ambasador yang menyampaikan pesan kampanye di dalam konten aplikasi game go sweat go ion. Dan untuk penggunaan media aplikasi game sendiri bisa kita sebutkan bahwa komunikator yang menyampaikan pesan dalam media ini adalah brand ambasador yaitu personil JKT 48.

Janis dan Kelley (Windahl, Signitizer \& Olson, 2006) mengemukakan tiga aspek yang mempengaruhi kredibilitas seorang komunikator atau pelaku kampanye:

Pertama, keterpercayaan (Trustworthiness). Keterpercayaan berkaitan dengan penilaian khalayak bahwa sumber informasi dianggap tulus, jujur, bijak dan adil, objektif, memiliki intergritas pribadi, serta memiliki tanggung jawab yang tinggi. Kedua, keahlian (Expertise). Faktor keahlian berhubungan dengan penilaian dimana sumber dianggap berpengetahuan, cerdas, berpengalaman, memiliki kewenangan tertentu dan menguasai skill yang bisa diandalkan. Dan terakhir, Daya Tarik Sumber. Dimana secara umum konsep ini meliputi penampilan fisik dan identifikasi psikologis. Penampilan fisik seseorang akan mempengaruhi bagaimana khalayak memersepsi sumber. Berbagai penelitian mengatakan bahwa orang yang menarik secara fisik dapat lebih mempersuasi orang lain. Dan pada daya tarik psikologis, salah satu komponen daya tarik psikologis adalah kesamaan (similarity). Dalam banyak hal, kemiripan antara pembicara dan khalayak dapat meningkatkan daya tarik yang membuat upaya persuasi menjadi lebih efektif.

Dalam hal ini, menurut pengamatan penulis, brand ambasador yang terdapat dalam aplikasi game sebagai media kampanye terlihat cukup memiliki 3 aspek yang diperlukan oleh seorang komunikator untuk membentuk kredibilitasnya.

Yang pertama mengenai keterpercayaan. Keterpercayaan disini penulis hubungkan dengan keterpercayaan JKT 48 sebagai brand ambassador produk Pocari Sweat di dalam kampanye ini. Pemilihan personil JKT 48 yang memiliki brand image yang sesuai dengan tujuan kampanye yaitu aktif bergerak dan berkeringat agar sesuai dengan khalayak kampanye yang merupakan anak muda.
Sehingga membuat khalayak percaya bahwa idiologi yang dikampanyekan dalam kampanye ini memang cara hidpu sehat yang baik untuk anak muda saat ini.

Kemudian mengenai keahlian, sesuai yang diucapkan oleh para informan, pemilihan para brand ambassador ini merupakan hal yang membuktikan bahwa keahlian merupakan modal agar bisa menjadi komunikator dalam kampanye ini. Keahlian disini yang ditentukan adalah keahlian dalam menyampaikan pesan kampanye, karena memang para komunikator diharuskan menyampaikan pesan secara menarik di dalam konten aplikasi game sebagai media kampanyenya. Dalam hal ini brand ambassador yang terpilih adalah 2 personil JKT 48 yaitu Ve dan Nabilah. Melihatnya talentanya sebagai artis profesional yang sangat di gandrungi anak muda saat ini, maka keahliannya dalam menyampaikan pesan pesan kampanye yang terdapat dalam aplikasi game sebagai media kampanye tidak perlu diragukan lagi.

Pesan dalam Game Go Sweat Go Ion sebagai Media KampanyePemasaran Produk Pocari Sweat. Tujuan kampanye hanya dapat dicapai apabila khalayak memahami pesan-pesan yang ditujukan kepada mereka. Ketidakmampuan mengonstruksi pesan sesuai dengan khalayak sasaran yang dihadapi merupakan awal dari kegagalan sebuah kampanye. Karena itu Pfau dan Perrot (1993) menasihati kita untuk berhatihati ketika mengonstruksi pesan kampanye agar tidak menjadi boomerang effect yang dapat menggagalkan pencapaian tujuan.

Johston (dalam Venus, 2005) menjelaskan setidaknya ada dua aspek penting yang harus diperhatikan yakni isi pesan dan struktur pesan. Pada aspek isi pesan, pelaku kampanye harus melihat pesan dari pendekatan emosional, rasa takut, kreativitas dan humor, serta pendekatan kelompok rujukan. Dan pada aspek struktur pesan, istilah struktur pesan merujuk pada bagaimana unsur-unsur pesan diorganisasikan. Pesan kampanye yang efektif adalah pesan yang menginformasikan dengan segera kejadian penting yang sedang terjadi di sekitar khalayak sasarannya, sehingga mudah ditanggapi dan dikenal oleh khalayak sasarannya.

Selain itu pesan yang efektif dipengaruhi pula oleh keefektifan medianya. Yang dimaksud disini adalah, pengonsepan pesan harus disesuaikan dengan jenis media yang digunakan agar pesan tersampaikan dan 
media tersebut menjadi efektif. Contohnya adalah bila kita menggunakan media televisi sebagai media kampanye, sangat tidak tepat jika konsep pesan yang diberikan hanya berupa suara tanpa visualisasi yang menarik. Atau jika kita menggunakan media baligho sebagai media kampanye, akan mengurangi minat dan pemahaman para target kampanye jika pesan hanya berupa tulisan panjang lebar atau sebaliknya hanya berisi gambar tanpa penjelasan.

Maka pengonsepan pesan pada media aplikasi game ini sangat mempengaruhi keefektifan pesan maupun media itu sendiri. Aplikasi game sebagai media kampanye ini merupakan media menawarkan konsep fun dalam penggunaan media nya tanpa mengurangi unsur unsur tujuan dari kampanye itu tersebut.

Materi dan isi suatu kampanye biasanya menyangkut tema, topik, dan isu apa yang ingin diangkat ke permukaan agar mendapat tanggapan; tujuan dari kampanye; program atau perencanaan acara dalam kampanye; dan sasaran dari kampanye yang hendak dicapai (Ruslan, 2002: 68).

XM Gravity pun memasukan keempat indikator tersebut dalam pesan kampanyenya. Tema, topik, dan isu yang ingin diangkat oleh XM Gravity adalah mengenai gaya hidup sebagian anak muda jaman sekarang yang cenderung jarang melakukan kegiatan fisik yang mana hal tersebut akan berakibat kurang baik bagi kesehatan anak muda tersebut. Jadi XM Gravity ingin membangun kesadaran anak muda yang tergolong dalam karakteristik lazy bum agar mereka sadar akan pentingnya bergerak dan berkeringat itu baik untuk tubuh mereka.

3 game dalam aplikasi go sweat go ion telah memiliki pesan yang sejalan dengan TVC yang ditayangkan di stasiun-stasiun televisi di Indonesia. Dalam merancang pesan di dalam game ini pihak XM Gravity tetap melihat aspek integrasi pesan dengan TVC yang ada di TV nasional, serta aspek storytelling dalam merancang game.

Storytelling yang di bangun dalam aplikasi game ini adalah sebuah benang mereh penghubung usaha integrated marketing communication yang di lakukan oleh pihak Pocari Sweat. Cerita dalam game yang di bangun tersebut juga merupakan sebuah bentuk dari penerjemahan positioning produk pocari sweat. Positioning sendiri dalam mekanisme penyampaiannya bukan hanya sebuah tagline semata, namun sudah di bangun melalui sebuah alur cerita dalam aplikasi game go sweat go ion ini. Secara lebih jelas menururt Renald Kasali, (Kasali dalam Sutisna, 2001: 258-259) hal-hal yang perlu diperhatikan sehubungan dengan pengertian positioning di atas sebagai berikut: Positioning adalah strategi komunikasi. Komunikasi dilakukan untuk menjembatani produk/merek dengan calon konsumen. Positioning bersifat dinamis. Artinya, bahwa persepsi konsumen terhadap suatu produk/ merek bersifat relatif terhadap struktur pasar/ persaingan. Positioning berhubungan erat dengan event marketing. Karena positioning berhubungan erat dengan citra di benak konsumen, pemasar harus mengembangkan strategi Marketing Public Relations melalui event marketing yang dipilih sesuai dengan karakter produk. Positioning berhubungan dengan atribut produk dan atribut yang dipilih harus unik. Positioning harus memberi arti dan arti itu harus penting bagi konsumen dan positioning harus diungkapkan dalam bentuk suatu pernyataan. Positioning yang semakin kuat mengenai minuman pengganti cairan tubuh sendiri merupakan sebuah hasil yang di lakukan dalam kampanye go sweat go ion sendiri.

Penggunaan Game Go Sweat Go Ion sebagai saluran Media Kampanye Pemasaran Produk Pocari Sweat berdasarkan konsep berikut. Klingemann dan Rommele (2002) mengartikan saluran kampanye sebagai segala bentuk media yang digunakan untuk menyampaikan pesan kepada khalayak.

Faktor yang mempengaruhi keefektifan media menurut Venus (2005: 92) disimpulkan bahwa sebaiknya menggunakan banyak sumber (saluran) untuk menjangkau khalayaknya, memasukkan kegiatan kampanye ke dalam komunitas yang lebih besar, dan tetap bersandar pada prinsip kesegeraan dalam meraih khalayak.

Dalam kampanye yang dilakukan XM Gravity ini, menggunakan dua media yang mengemas pesan kampanyenya. Yang pertama adalah aplikasi game go sweat go ion sebagai media utama dan didukung oleh media digital lainnya seperti banner digital, youtube trueview (video iklan di youtube), Google Display Network. Namun penulis hanya membahas mengenai penggunaan saluran atau media kampanye go sweat go ion yang berupa aplikasi 
game digital saja.

Dalam membahas efektivitas media kampanye, selain untuk melihat efektivitas komunikator dan pesan, media itu sendiri perlu dianalisis efektivitasnya. Sesuai dengan yang telah dipaparkan diatas, game sebagai media kampanye go sweat go ion yang diinisiasi oleh XM Gravity selaku agency periklanan digital produk Pocari Sweat di Indonesia ini merupakan media baru yang jarang ditemui sebelumnya. Karena game biasanya lebih sering digunakan sebagai media hiburan.

Jika dilihat secara umum, ada satu faktor yang menyebabkan media game ini terlihat efektif sebagai media kampanye: yaitu daya jangkaunya yang luas karena media ini berupa aplikasi digital yang dengan mudah dapat di download oleh para khalayak di dunia maya dan penyebarannya melalui viral Marketing atau Viral Advertising yang menurut Trisno:

"Buzzwords referring to marketing techniques that use pre-existing social networking services and other technologies to try to produce increases in brand awareness or to achieve other marketing objectives (such as product sales) through self-replicating viral processes, analogous to the spread of viruses or computer viruses (cf. Internet memes and memetics) (Trisno, 2013)

atau dalam bahasa Indonesia diartikan sebagai sebuah cara pemasaran yang menggunakan jejaring sosial dan teknologi yang mencoba untuk meningkatkan kesadaran merek atau untuk mencapai objektif pemasaran seperti replikasi diri dalam proses viral, ini dianalogikan seperti penyebaran sebuah virus. Aplikasi ini memang dengan cepat menyebar ke khalayak sasaran kampanye go sweat go ion yaitu anak muda. Hal ini terbukti dari banyaknya publik yang antusias mengunduh game tersebut. Terdapat lonjakan yang cukup signifikan antara awal peluncuran aplikasi yaitu tanggal 7 November 2013 sampai dengan tanggal 25 November 2013.

Menurut data tersebut, terdapat 15.365 user yang telah men-download aplikasi tersebut, dimana para user tersebut juga bermain aktif aplikasi go sweat go ion. Hal di atas menunjukan pula bahwa pendekatan menggunakan game berupa aplikasi digital yang di lakukan oleh pihak XM Gravity cukup di sukai oleh para khalayak yang mayoritas merupakan para anak muda.

Hal ini tentunya cukup menggembirakan karena tingginya partisipasi dari para khalayak kampanye yang tentunya di harapkan dapat merubah pandangan mereka mengenai pentingnya bergerak dan berkeringat sehingga di harapkan adanya perubahan gaya hidup para khalayak yang terpapar dengan informasi di dalam aplikasi go sweat go ion ini.

Untuk menganalisis efektivitas suatu media, penulis harus mengetahui siapa sasaran kampanyenya, apakah media ini terbilang cocok untuk digunakan atau apakah membuat kampanye ini menjadi tidak efektif. Karena tidak mungkin pelaku kampanye menggunakan media kampanye koran bersegmentasi berita, jika sasarannya adalah anak sekolah, atau pelaku kampanye menggunakan media sosial sebagai media kampanyenya jika sasaran kampanyenya adalah orang berusia lanjut di sebuah desa. Maka dari itu, tipe atau segmentasi khalayak mempengaruhi keefektifan suatu media kampanye yang digunakan.

Seperti yang telah penulis sering paparkan dan didukung oleh jawaban dari para informan, target sasaran atau khalayak dari kampanye ini adalah anak muda yang berkarakteristik dalam golongan lazy bum, lazy bum ini adalah orang orang yang memiliki beberapa alasan untuk tidak melakukan kegiatan yang menggunakan unsur fisik di dalamnya. Alasan alasan mereka seperti terlalu malas untuk bergerak, merasa terlalu panas di luar ruangan, merasa olah raga dapat di lakukan besok hari, merasa terlalu mengantuk, dan tidak ingin berolah raga sendirian.

Selain itu para lazybum ini memiliki beberapa kebiasaan menarik seperti sangat menyukai bermain video games, sangat menyukainongkrong bersama teman teman, suka untuk menonton TV, dan suka tidur. Kebiasaan atau hobi ini dijadikan sebuah landasan dalam merancang media pendekatan apa yang harus di gunakan oleh XM Gravity selaku pihak yang akan membuat sebuah kampanye digital agar hasil dari kampanye ini dapat berjalan efektif dan efisien.

Efek yang Diharapkan dalam penggunaan Game Sebagai Media Kampanye Pemasaran Produk Pocari Sweat. Efektivitas suatu media berdasarkan hasil wawancara adalah jika 
mampu menyampaikan pesan dan menghasilkan tujuan yang diharapkan. Dilihat dari tujuan kampanye yang berorientasi pada perubahan perilaku khalayak khususnya anak anak muda yang bermain game go sweat go ion, efektivitas tersebut cukup sulit untuk di ukur karena pengukuran perubahan perilaku harus berbasis kepada riset yang mendalam kepada para khalayak yang berpartisipasi sebagai pemain dalam permainan game ini. Namun menurut pihak XM Gravity, tolak ukur dari kampanye yang menggunakan game ini sebagai media kampanye dapat di ukur melalui banyaknya khalayak yang mendownload game ini.

Hal tersebut dapat menjadi sebuah acuan dari kampanye yang menggunakan game ini sebagai media kampanye, apakah banyak yang berpartisipasi di dalam game ini atau tidak, karena pada dasarnya media game sebagai media kampanye, jangkauan dari media bukan satu-satunya yang menjadi tolak ukur dalam permainan tersebut namun keaktivan dalam memainkan game juga menjadi sebuah tolak ukur. Berbeda dengan media Above the line seperti TV, Radio, atau koran yang mementingkan jangkauan sebagai kekuatan utama pada media tersebut, media game frekuensi mengakses media menjadi sebuah hal penting dalam menyampaikan tujuan yang hendak dicapai dalam kampanye ini.

Ukuran pengaruh atau efek media game on-line dalam riset yang dilakukan, merupakan efek semu (pseudo effect) yang mengandalkan prediksi, bahwa perilaku anak muda yang mendownload game akan melakukan tindakan sesuai instruksi pada games tersebut. Hal ini tentu, merupakan harapan dari produsen, dimana sepersuasif dan semudah mungkin intruksi itu disajikan agar konsumen atau para downloader menggunakan atau memainkan games tersebut atau berubah menjadi user yang aktif.

Jika mereka telah menjadi bagian dari adopter yang telah men-download aplikasi dan menggunakannya, atau disebut sebagai user

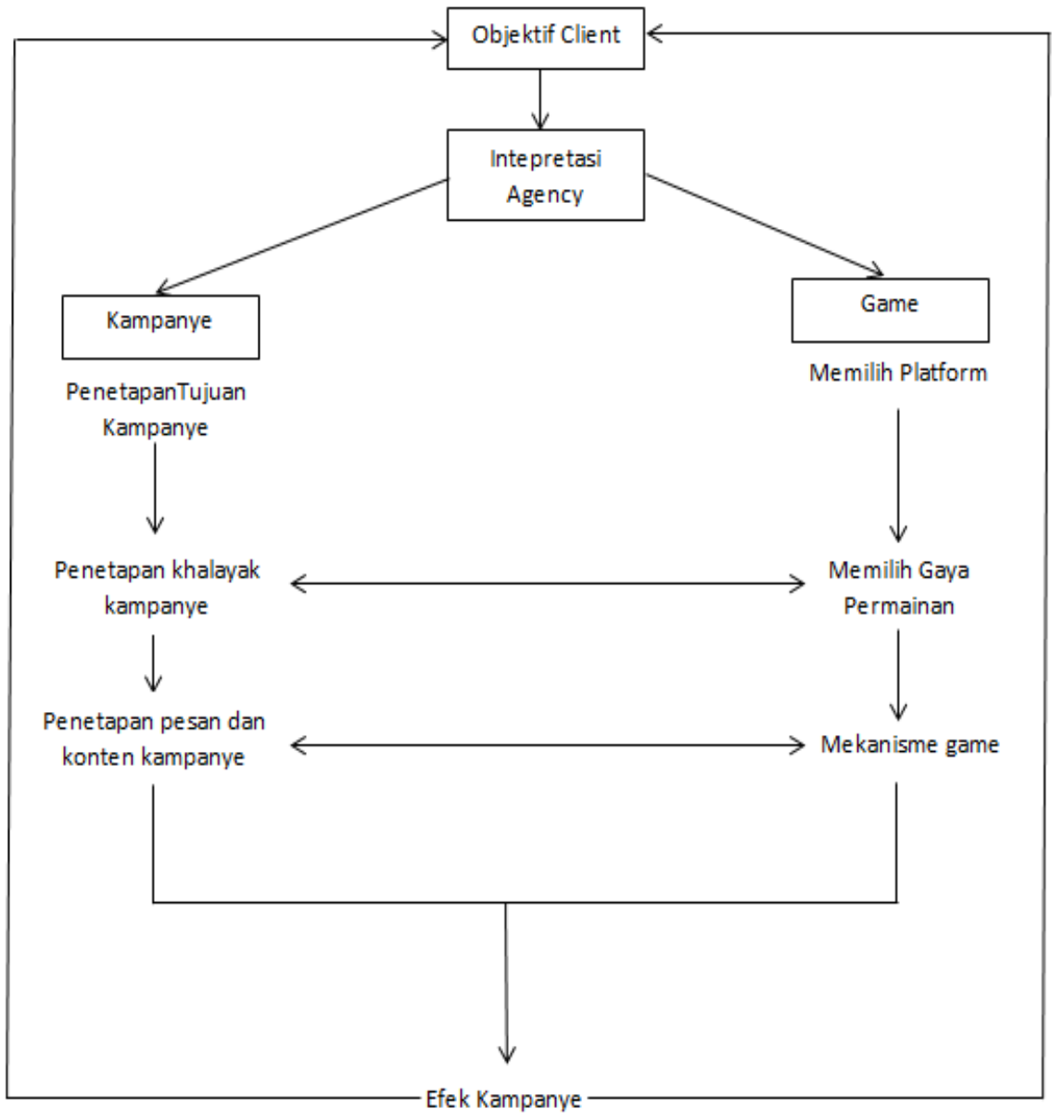


yang aktif akan menjadi paham akan pentingnya bergerak. Bergerak adalah end-point yang berkaitan dengan pegeluaran atau pembakaran energy atau berolahraga. Berubahnya persepsi mengenai bergerak itu tidak sulit, bisa dilakukan sambil memainkan game, adalah pergeseran persepsi. Sebelumnya selalui dipersepsikan bahwa bermain game adalah pasif atau diam.

Hal ini tentunya cukup menggembirakan karena tingginya partisipasi dari para khalayak kampanye yang diharapkan dapat merubah pandangan mereka mengenai pentingnya bergerak dan berkeringat sehingga di harapkan adanya perubahan gaya hidup para khalayak yang terpapar dengan informasi di dalam aplikasi go sweat go ion ini.

Selain jumlah download pada aplikasi go sweat go ion, menurut informan lain jumlah penambahan jumlah fans atau jumlah followers di media digital pocari adalah berkat kampanye yang menggunakan media digital ini, sesuai dengan core utama dalam kampanye ini yaitu dunia digital.

Selain penambahan jumlah fans dan followers pada media sosial digital dari produk pocari sweat, peningkatan traffic pada website utama pocari sweat juga di pengaruhi oleh kampanye digital ini. Yang lebih menggembirakan lagi adalah peningkatan traffic pada website utama pocari sweat bersifat organik atau dapat di katakan bahwa para khalayak dalam mengakses website utama ini didasari oleh kesadaran oleh para khalayak bukan karena adanya sumber link menuju halaman utama website pocari sweat atau di dorong oleh sebuah advertisement.

\section{SIMPULAN}

Latar belakang Agency XM Gravity menggunakan game sebagai media kampanye Pocari Sweat adalah didasari oleh banyaknya anak muda di indonesia saat ini yang kurangnya kepedulian akan pentingnya bergerak dan berkeringat. Pihak XM Gravity selaku digital agency dari pihak PT.Amerta Indah Otsuka di tuntut untuk dapat menghasilkan sebuah campaign digital yang dapat merubah pola pandang anak muda tentang bergerak dan berkeringat, maka di pilihlah sebuah media aplikasi game sebagai pola pendekatan utama dalam kampanye ini sehingga anak-anak muda yang tergolong dalam kategori lazy bum dapat sadar akan pentingnya bergerak dan berkeringat, dan ketika anak anak muda ini melakukan aktifitas bergerak dan berkeringat dengan media game ini, mereka di harapkan dapat menjadi konsumen produk pocari sweat.

Komunikator yang bertugas di dalam penyampaian pesan menggunakan media game ini bisa dikatakan cukup kredibel dalam menggunakan media baru ini, sehingga media game menjadi media yang efektif dalam kampanye ini. Hal ini disebabkan oleh kredibilitas yang dimiliki oleh komunikator sangat memadai. Selain dilihat dari sisi keahlian, faktor keterpercayaan dan daya tarik yang dibagi menjadi daya tarik fisik dan psikologis pun dapat dipenuhi oleh komunikator ini. Bisa dilihat dari fakta bahwa para komunikator ini merupakan anggota group idol terkenal yaitu JKT 48. Selain itu usia mereka yang sesuai dengan khalayak atau target kampanye pun menjadi daya tarik komunikator.

Pesan yang dikemas dalam game sebagai media kampanye ini terbilang baik dan tepat, sehingga game sebagai media kampanye untuk produk pocari sweat ini dinilai cukup efektif. Pesan yang simpel mudah dibaca oleh khalayak membuat khalayak sadar mengenai identitas pembuat kampanye ini yaitu Pocari Sweat. Selain itu berkaca dengan tujuannya yaitu untuk menimbulkan awareness terhadap gaya hidup sehat di kalangan anak muda dan banyak anak muda yang ikut serta dalam kampanye ini, sehingga tujuan awareness pun tercapai. Dari segi pemasaranpun banyak pula anak muda yang tergolong dalam katagori lazy bum mulai mencoba produk pocari sweat.

Penggunaan game sebagai media kampanye produk pocari sweat dinilai cukup unik dan efektif dalam menimbulkan awareness, hanya saja di butuhkan perawatan dan inovasi yang harus terus di lakukan agar game tersebut tidak menjadi membosankan dan terus di sukai oleh para khalayak yang memainkannya. Selain itu penyesuaian teknologi di dalam game dengan infrastruktur pendukung di Indonesia harus di perhatikan dengan serius oleh para pemasar yang hendak memanfaatkan game sebagai media komunikasi dalam kampanye yang hendak di bangun.

Kategori khalayak atau target kampanye yang dituju terbilang membuat kampanye menggunakan game adalah sebagai media kampanyenya menjadi terbilang efektif. 
Dikarenakan karena memang bermain game mobile di gadget sudah menjadi gaya hidup di kota kota besar khususnya di kalangan anak muda yang memiliki smartphone atau pc tablet, game go sweat go ion yang di sasar kepada anak muda pun sudah terbilang sudah sangat tepat karena kebiasaan mereka yang suka bermain game dan memiliki gadget pintar, sehingga tujuan untuk menimbulkan kesadaran para target kampanye tersebut dapat tercapai dengan optimal.

Melihat efek yang terjadi setelah dilakukannya kampanye ini, maka dapat disimpulkan bahwa kampanye dengan memakai game sebagai media kampanyenya dinilai sebagai media yang efektif bagi kampanye produk pocari sweat. Lebih dari 15.000 peserta yang ikut mendownload aplikasi ini dalam jangka kurang dari 1 bulan terbilang jumlah yang cukup tinggi. Antusiasme yang tinggi dari para khalayak juga menjadikan tolak ukur dalam kampanye ini, hal ini tergambar dari banyaknya khalayak yang berlomba lomba untuk mendapatkan nilai yang tinggi sehingga dapat memuncaki leaderboard game go sweat go ion.

Dari analisis yang didapat dari penelitian ini, penulis telah mencatat beberapa saran yang diharapkan dapat menjadi masukan positif bagi XM Gravity maupun pelaku kampanye lainnya, ialah sebagai berikut: Game memang merupakan media baru yang terbilang unik untuk dijadikan media kampanye. Game memiliki sebuah karakteristik yang unik karena memiliki unsur fun sehingga para khalayak dengan senang hati terpapar dengan pesan yang hendak di sampaikan oleh perancang kampanye.

Namun dalam penggunaannya, media game ini harus melakukan inovasi yang terus menerus karena sifat manusia yang cepat bosan. Perbaikan grafik dan konten dalam game yang ada menjadi hal yang cukup penting karena menjadi salah satu daya tarik dari kampanye menggunakan game itu sendiri. Terlebih lagi dengan adanya penyesuaian game dengan infrastruktur ICT yang ada di Indonesia harus benar-benar diperhatikan, karena teknologi secanggih apapun apabila tidak didukung oleh infrastruktur yang memadai tidak akan menghasilkan sebuah game yang menarik bagi masyarakat indonesia.

\section{DAFTAR PUSTAKA}

Alia, S. S. (2015). Pengguna smartphone di indonesia paling suka unduh game. Diakses dari http://teknologi.news.viva.co.id/news/ $\mathrm{read} / 581994$

Cresswell, J. W. (1998). Qualitative inquiry and research design: choosing among five tradition. London: Sage Publication.

Daymon, C. (2002). Riset kualitatif dalam public relations dan marketing communications. Yogyakarta: Bentang Pustaka.

Devito, J., A. (2011). Komunikasi antarmanusia. Tanggerang Selatan: Karisma Publishing Group

Fill, C. (1995). Marketing communication, framework theories, application. London: Prentice Hall.

Kartajaya, H. (2005). Marketing yourself:kiat sukses meniti karir dan bisnis. Jakarta: MarkPlus\&Co.

Klingemann, H. D. \& Rommele, A. (2002). Public information campaigns and opinion research: a handbook for the student and practitioner. London: Sage Publications.

Mulyadi, I. (2012). Gaming your market. Jakarta: Publishing One.

Pfau, M., \& Parrot, R. (1993). Persuasive communication campaigns. London: Pearson.

Prisgunanto, I. (2006). Komunikasi pemasaran, strategi dan taktik. Bogor: Ghalia Indonesia.

Ruslan, R. (2002). Kiat \& strategi kampanye public relations. Jakarta: RajaGrafindo Persada.

Smith, B. \& Pulford. (1999). Marketing communication strategy. NewYork: Sage.

Sutisna. (2001). Perilaku konsumen \& komunikasi pemasaran. Bandung: Remaja Rosdakarya

Trisno, R. (2013). Pengenalan viral marketing. Diakses dari http://www.viral.web.id/artikel/ pengenalan-viral-marketing-beberapa kutipan.htm

Venus, A. (2005). Manajemen kampanye. Bandung: Simbiosa Rekatama Media

WebFinance. (2015). Advergame. Diakses dari http://www.businessdictionary. com/definition/ advergame. html\#ixzz3QYmdQmvz

Windahl, S., Signitizer, B. H. \& Olson, J. T. (2006). Using communication theory: an 
introduction to planned communication. London: Sage Publications.

Yin, K. R. (2006). Studi kasus, desain dan metode. Jakarta: Raja Grafindo Persada.

Pocari Sweat. (2013). Diakses dari http://www. pocarisweat.co.id/gosweatgoion/ 25/10/2014 